Factor Table giving the Complete Decomposition of all Numbers less than roo,ooo

Prepared independently by J. Peters, A. Lodge and E. J. Ternouth, E. Gifford, and collated by the British Association Committee for the Calculation of Mathematical Tables. Pp. xv +292. (British Association for the Advancement of Science Mathematical Tables, Vol. 5.) (London : British Association, 1935.) $20 s$. net.

THE theory of numbers, going back at least as far as the time of Pythagoras, differs in many respects from other branches of mathematics, a fact that may explain the attraction of the subject, not only for the majority of mathematicians (though a minority dislike it intensely), but also for enthusiastic amateurs such as the late Lieut.-Col. A. J. C. Cunningham, whose generous bequest has made possible the production of this and two preceding volumes of British Association tables.

No other mathematical subject comes so near to being a science of observation and description, and the data to be observed are largely connected with factorisation of numbers. The study of congruences, quadratic and power residues, continued fractions, quadratic forms, and other more recent theories have arisen as by-products in the process of factorisation. The systematic treatment of the problem may be said to have started with Eratosthenes in the third century B.c., but the first extensive factor table was published by Brancker in 1668. Others were published by Chernac (1811), Barlow (1814), Inghirami (1832), Vega (1849), Hinkley (1853), Jones (4th ed., 1893), and Gifford (1931), while there also exist some of much greater range, notably Lehmer's "Factor Table for the First Ten Millions" (1909).

The great defect of factor tables is their liability to contain errors, which are not only more difficult to detect than is the case with tables of the ordinary continuous mathematical functions, but also more serious in their consequences. The present table rests on the comparison of three tables prepared independently by Prof. J. Peters, Prof. A. Lodge and Miss E. J. Ternouth, and Mrs. E. Gifford, assisted by no less than eighteen volunteer proof-readers. It may not be in mortals to command accuracy, but in any event the authors deserve it. The whole of the work of computers and readers has been voluntary, and the cost of production consists entirely of that of organisation and printing.

H. T. H. P.

\section{The Beginnings of Systematic Bibliography}

By Theodore Besterman. Pp. xi $+81+12$ plates. (London: Oxford University Press, 1935.) 21s. net.

THIs beautifully printed and illustrated work forms the third of a series known as the Oxford Books on Bibliography. In Part 1, Mr. Besterman traces the development of systematic bibliography from its earliest beginnings to the end of the seventeenth century. Bibliographies of very limited scope are shown to have existed before the invention of printing. In the second century, for example, Galen com. posed a classified list of his own very numerous writings, which was afterwards printed (1525). The greatest of early bibliographers was Conrad Gesner, but Mr. Besterman deprives him of the title of 'father of bibliography'. This honour, previously accorded to him by some authors, he awards to Johann Tritheim, who published at Basle in 1494 a bibliography listing some 7,000 works, mainly ecclesiastical. To Gesner still belongs the credit of being the first universal bibliographer, and a chapter is devoted to a description of this author's biblio. graphical works. It is interesting to note that in his "Pandectarum sive partitionum universalium" (Zurich, 1548), in which the books listed are classified by subjects, works of scientific interest have been separated under headings such as geometry and optics, astronomy, natural philosophy, etc. Gesner's bibliographies were restricted to works in the learned languages, Greek, Latin and Hebrew.

In subsequent chapters Mr. Besterman discusses particularly the evolution of national and subject bibliographies. One of the earliest known subject bibliographies is Symphorien Champier's "De mede. cine claris scriptoribus" (Lyons, 1506). This is the first medical bibliography, and lists works in European, as well as classical, languages. Pierre Borel's "Bibliotheca Chimica" (Paris, 1654), the first chemical bibliography, perhaps deserves to have received a mention.

Part 2 consists of a list of all important bibliographies published up to the end of the sixteenth century.

Mr. Besterman's scholarly work will appeal to all bibliophiles, and may not be without practical value to those whose researches lead them into the bypaths of sixteenth and seventeenth century literature.

In the Heart of Europe :

Life in Czechoslovakia. By Dr. Gerald Druce. Pp. $228+30$ plates. (London : George Allen and Unwin, Ltd., 1936.) 6s. net.

THIs recent addition to the already numerous works on Czechoslovakia attempts to combine a general account of the country with guide-book details intended to help the tourist. Too much space is wasted by such statements as "life in provincial towns is naturally quieter than in the capital . . . it need not, however, be dull". A chapter is devoted to education, science, religion and art, fourteen pages being given to science. The influence of the exiled Komensky (Comenius) on the formation of the Royal Society in England and on contemporary American thought is recalled; the Czech origin of Purkyne and Mendel is naturally recorded, and many of the leading names of the present day and the last century are mentioned. But the information concerning their contributions to knowledge is too casually expressed to have much value. Thus one man of science has "added greatly to our knowledge of the useful and harmful bacteria"; another's special study "will eventually prove of value both to industry and to science itself", whilst a third "made many contributions to technological methods". Apart from the Frenchman Barrande, the only geologist selected for mention is Slavik. The volume has an excellent map prepared by the military cartographical institute of Prague.
L. D. S. 